\title{
Music Education in the Covid-19 Pandemic: Challenges of Distance Learning and Digital Platforms
}

\author{
Kheren Sara Octaviani ${ }^{*}$ \\ ${ }^{I}$ Faculty of Languages and Arts, Universitas Negeri Yogyakarta, Yogyakarta, Indonesia \\ ${ }^{*}$ Corresponding author. Email: kheren2869fbs.2017@student.unv.ac.id
}

\begin{abstract}
This article discusses the challenges faced by music education students as prospective teachers who were carrying out teaching practice at schools located in Yogyakarta Special Region, Purworejo, Solo, and Medan during the Covid-19 pandemic. Teaching and learning activities that had to be carried out online were a dilemmatic story because the students were required to be more creative and innovative in preparing and developing teaching materials to run the music learning properly. The use of various digital platforms was a solution for teachers to provide good services to students. This is an innovation in the world of music education that has never been done before the Covid-19 pandemic.
\end{abstract}

\section{Keywords: Learning Activities, Music Education, Covid-19 Pandemic, Digital Platforms}

\section{INTRODUCTION}

Covid-19 pandemic has significantly impacted the structure of human life. Since the Indonesian government first announced that two citizens tested positive for Covid-19 on March 2, 2020, self-quarantine has been enforced on the entire community. Therefore, activities that are usually carried out outside must be temporarily stopped and done from home, which is referred to as Work from Home (WFH).

Large-scale social restrictions provide an effect on the world of music education. The chaotic situation requires teaching and learning activities to be carried out online. This condition then becomes a challenge for all music teachers, including music education students, who were conducting educational practice. They were required to immediately adapt to teaching and learning activities that had shifted from conventional to online mode. In fact, the music learning material is mostly practical; that is why it becomes a challenge for them.

Music teachers and students finally took advantage of various digital platforms to support their distance learning. In addition to facing new challenges, this situation also gave them new opportunities to be more creative and innovative in developing ideas and trying new ways that had never been executed before in music education. The freedom made them more flexible in conducting learning, which could be adjusted to the circumstances of students who joined the class from home.
This condition finally makes music education go hand in hand with the development in the postmodern era. The learning carried out could be more contextual between music education and society in the postmodern era. In addition, prospective teachers could prepare themselves to be graduates consistent with the concept of independent learning and a driving-force teacher, which is a breakthrough initiated by the Indonesian Minister of Education and Culture, Nadiem Makarim, to face the 21 st-century education.

\section{LITERATURE REVIEW}

\subsection{Distance Learning}

Distance learning is an ability that develops in knowledge and behavior as a result of learning experiences that are limited by time and distance; thus, learners do not share the same situations in their learning. From distance learning, a definition of distance education is questioned. Distance education is instructional learning, where situations, times, and even geographic conditions limit the learning process by providing no direct contact between students and teachers [8].

The situation of distance education can be grouped into two categories as follows:

a. Synchronous distance education. Synchronous situations provide opportunities that allow real interaction between teachers and students. An 
example is the use of video conferencing and online chat rooms.

b. Asynchronous distance education. Asynchronous situations do not provide direct interaction between teachers and students. An example is the use of e-mail and web-based instructions or tutorials [8].

The Covid-19 pandemic in Indonesia is very influential to the world of education. To prevent and minimize the spread of the virus, learning must take place remotely. On March 24, 2020, the Minister of Education and Culture of the Republic of Indonesia, Nadiem Makarim issued a policy in Circular Number 4 Year 2020 concerning the Implementation of Education Policies in the Emergency Period of the Spread of Coronavirus Disease (COVID-19) [6]. The learning process is carried out at home with the following conditions:

a. Meaningful experiences that do now place burden on students to attain all curriculum achievements for graduation or grades are provided for them through online/distance learning (from home);

b. Making life skills-based education regarding Covid 19 situation the focus of learning from home;

c. Several considerations such as students' interests, conditions, and gap in learning facilities at home are taken into account to create a variety of assignments and learning activities;

d. Evidence or products of Learning from Home are given qualitative and useful feedback, with no provided quantitative score $[6,10]$.

\subsection{Digital Platforms}

Along with the times, Indonesia faces technological development with the use of digitalization [4]. Especially, in the context of the Covid-19 pandemic, the use of digital platforms is considered as a solution to help parents, teachers, schools, and school administrations facilitate student learning during the period of school closure [14].

Learning platforms are used as virtual scenarios to promote educational innovation and professional development, especially in the education personnel model, which emphasizes cooperation. Learning platforms open new places that go beyond conventional learning space and time. Important communication features in digital platforms include discussion forums, message exchanges, and websites.

\section{RESEARCH METHOD}

The research method used in this research was qualitative digital ethnography. The data were collected through interviews, document analysis, and literature study related to the topic. The researcher analyzed and organized the data into categories, double-checked, and coded the data [2]. For the data validation, the steps applied were triangulation, reflexivity, and research deepening.

The participants were four undergraduate students in music education, who were taking educational practice. The participants taught at the schools based on their domiciles, which are located in Yogyakarta Special Region, Purworejo, Solo, and Medan. Since the research was conducted during the Covid-19 pandemic, interviews were conducted indirectly via WhatsApp. The research employed a case study strategy. A case study is a method used to explore processes, activities, and events [2].

\section{FINDINGS AND DISCUSSION}

This section provides the results of the research and the discussion section.

\subsection{Research Findings}

Based on the interviews conducted with four teaching-practice students/prospective teachers, there were three challenges they experienced when carrying out online teaching activities.

\subsubsection{Limitations in Delivering Material}

Most of the teaching-practice students found limitations in delivering materials in online music learning. Teaching practices, which were usually carried out conventionally, must switch to online mode using electronic media to deliver the materials, such as PowerPoints, Google Classrooms, online discussion rooms, and others.

One of the teaching-practice students said that the online mode in the material delivery made it difficult for students to understand the teacher's explanation. Particularly, the difficulty was found when the teacher explained a practical material, such as singing practice with the right technique and position. Before the pandemic, the students could ask and obtain answers right away, but in online learning, they sometimes found limitations due to unstable signal or delay.

Differences in student understanding and acceptance from one another affect the difficulties in distance learning. Therefore, with online learning, teachers are required to develop brief and concise materials to be clearly understood by all students and to provide no burden to study.

\subsubsection{Inadequate Facilities}

The second challenge faced by the teaching-practice students is the unavailability of adequate facilities from the school for each student to study at home. On the online learning, the facilities used are electronic devices 
such as laptops, computers, or cell phones, and internet access, which are costly enough.

Regarding the results of interviews conducted with the four teaching-practice students, they said that the absence of a mobile data subsidy from schools was an obstacle in this online learning process. Students who were not given subsidized internet quota/mobile data complained. Teaching and learning activities were also hampered when there were students who did not participate in learning due to the unavailability of internet quotas, cell phones, or laptops. If the teacher wanted to teach on virtual meetings, he/she must consider and think about the highly used mobile data. Moreover, teaching practice is not an instant process; it takes a long time. Such issues urged teachers to always repeat the explanation to accommodate students who were left behind in the learning process. One of the teaching-practice students conveyed that to overcome students' obstacles dealing with mobile data, laptop, computer, or cell phone, the teachers provided offline services done by dropping assignments at school and they would be taken by certain students.

\subsubsection{Digital Platform Use}

Education in Indonesia which still implements distance or online learning indirectly requires teachers to be more innovative and creative in managing their learning. Every teaching-practice student who was interviewed revealed that one of the challenges was that they had to create learning media using available digital platforms, as media and support for distance or online learning.

When the teachers prepared for the next lesson, they also must think about what platform was used to deliver the material to study at that time. Most of them used Zoom and Google Meet platforms to teach, so students could directly join the virtual class. However, because they considered the students' mobile data that would be used up a lot, they also thought of finding the right solution, by making videos that could later be accessed via Google Drive or YouTube. The teachers also used the WhatsApp Group to have a discussion with students, so they could ask anything they did not understand. In addition, the teacher could provide answers and additional explanations to help students understand the explained materials.

Another case happened when teachers would deliver theoretical materials. They usually developed the learning materials in a PowerPoint first. Then, in teaching, they shared the materials through the WhatsApp Group. Usually, the teacher gave students time to read and understand the materials, and then they had a discussion and question-answer session.

In giving assignments, the teachers employed Google Classroom which would be accessed by the students later. Through this platform, the teachers could explain the assignments and how to submit them. For the learning evaluations, the teachers employed Google Forms which could be directly accessed by students.
Based on the interviews conducted with four practical students, the digital platforms they often used to support online learning are as follows:

1. YouTube - the largest video site and educational channel $[1,14]$

2. WhatsApp - digital video and audio call sites, message exchange, and digital application content [14]

3. Zoom - a site for video and audio conferencing, collaboration, chats, and webinars [14]

4. Google Classroom - a site used to help create classrooms in an organized manner [14]

5. Google Meet - a site for conferences and audios with up to 250 participants, which can present documents/slides by displaying the entire screen or application window only [13]

6. Google Form - a site used to create forms for data collection purposes (surveys and quizzes) [9]

\subsection{Final Results}

The results of this study are three challenges faced by four teaching-practice students in music education, who were taking educational practice in their domiciles. The challenges are 1) limitations in delivering materials, 2) inadequate facilities, and 3) use of digital platforms. During the Covid-19 pandemic, they had to conduct online teaching and learning activities that had never been carried out before.

\section{CONCLUSIONS}

Based on the results and discussion of the research, three challenges were experienced by the four teaching-practice students at Music Education Department when carrying out online teaching activities. The three challenges include 1) limitations in delivering materials, 2) inadequate facilities, and 3) use of digital platforms.

The ongoing music education during the Covid-19 pandemic has provided many new experiences for teaching-practice students. The uncertain period of school closure made the prospective teachers finally take advantage of various digital-based platforms to support their distance teaching. As a result, they were encouraged to make a change as an innovation.

Apart from the various challenges, online teaching situations provide them with new opportunities. Prospective teachers are becoming more creative and innovative and have more space to combine digital media and music education in their teaching practices. They also become more familiar with digital-based learning in this postmodern era. Teaching practices during the Covid-19 pandemic urge prospective teachers to prepare themselves to be qualified graduates in 21 st-century education. 


\section{REFERENCES}

[1] Loudermilk, Michelle Lynn. The Use of Aesthetics in a Comprehensive Art Curriculum. Theses, Dissertations, and Capstones. 2002. Unpublished.

[2] Bahrul, B. Sejarah YouTube, Platform Berbagi Video Terbesar di Dunia [History of YouTube, World's Largest Video Sharing Platform]. (2020) Downloaded on August 29, 2020, from LOOP: https://loop.co.id/articles/sejarah-youtube/full

[3] Creswell, J. W. Research Design Pendekatan Metode Kualitatif, Kuantitatif, dan Campuran [Research Design: Approaches to Qualitative, Quantitative, and Mixed Methods]. Yogyakarta: Pustaka Pelajar (2016): 5.

[4] Daubney, Alison, and Martin Fautley. Editorial Research: Music education in a time of pandemic. British Journal of Music Education 37.2 (2020): 107-114. DOI: https://doi.org/10.1017/S0265051720000133

[5] Efendi, Neng Marlina. Revolusi Pembelajaran Berbasis Digital (Penggunaan Animasi Digital Pada Start Up Sebagai Metode Pembelajaran Siswa Belajar Aktif) [Digital-Based Learning Revolution (Use of Digital Animation at Start Up as a Learning Method for Active Learning Students)]. Habitus: Jurnal Pendidikan, Sosiologi, \& Antropologi 2.2 (2018): 173-182. DOI: https://doi.org/10.20961/habitus.v2i2.28788

[6] Elliott, D. J. Music Education Philosophy. The Oxford Handbook of Music Education, Volume 1. Oxford University Press. (2012): 1-30. DOI: 10.1093/oxfordhb/9780199730810.013.0005

[7] Kebudayaan, Menteri Pendidikan dan, Republik Indonesia. Surat Edaran Nomor 4 Tahun 2020 tentang Pelaksanaan Kebijakan Pendidikan dalam Masa Darurat Penyebaran Coronavirus Disease (COVID-19) [Circular Number 4 of 2020 concerning Implementation of Education Policies in an Emergency for the Spread of Coronavirus Disease (COVID-19).]. (2020).

[8] Kemdikbud. Reformasi Pendidikan Nasional Melalui Merdeka Belajar [National Education Reform through Merdeka Belajar]. Kemdikbud, 6 May 2020 , www.kemdikbud.go.id/main/blog/2020/05/reforma si-pendidikan-nasional-melalui-merdeka-belajar.

[9] King, Frederick B., et al. Defining distance learning and distance education. AACE journal 9.1 (2001): 1-14.

[10] Love, Christa. 5 Reasons to Use Google Forms with Your Students. TechnoKids, 18 Dec. 2014, www.technokids.com/blog/apps/reasons-to-use-go ogle-forms-with-your-students.

[11] Mulyanti, Budi, Wawan Purnama, and Roer Eka Pawinanto. Distance learning in vocational high schools during the covid-19 pandemic in West Java province, Indonesia. Indonesian Journal of Science and Technology 5.2 (2020): 271-282. DOI: https://doi.org/10.17509/ijost.v5i2.24640

[12]Rajshree. Themes of Postmodern Education. International Journal of Scientific and Research Publications 2.12 (2012): 1-5.

[13]Rikowski, Glenn, and Peter McLaren. Postmodernism in educational theory. Marxism against postmodernism in educational theory (2002): 3-13.

[14] Soltero, J. Google Meet Siap Memfasilitasi Pertemuan Video Anda, Gratis. Google Cloud, 12 May. 2020, www.cloudblog.withgoogle.com. , Downloaded 29 August 29, 2020.

[15] UNESCO. Distance Learning Solutions. UNESCO, 7 July 2020, en.unesco.org/covid19/educationresponse/solutions 